\title{
Hedges as Modality and Point of View in Narratives in Terms of Simpson's Model
}

\author{
https://doi.org/10.32792/utq/utj/vol11/1/6
}

\author{
By \\ Assist. Prof. Sa'ad Salman Abdullah \\ Albasrah University \\ Assist .Lect. Adawyia Sattar Abood \\ Educational Directorate of Dhi Qar
}

\begin{abstract}
Language is employed for not only conveying factual information but also expressing one's attitudes and opinions about the truth of the proposition contained in an utterance. The study offers a framework for analyzing the linguistic resources of intersubjectivity and dialogism which perhaps is considered one of the most fascinating subjects in a linguistic study.

Attempts are being made to realize how epistemic modality, which has been treated under such headings as : evidentiality, hedging ; concession, is textualized in literary texts by adopting Simpson's (1993) model of "modality and point of view" .It may be important to say that we have taken this modal because modality and point of view have an in- separable relationship. Thus this modal has been used to analyze fictional stories because much of the feel of a text is allowed to be attributed to the type of point of view or authorial interests it exhibits . The paper chiefly comprises three parts : The first investigates the theoretical background of hedging, whereas the second presents a pragmatic analysis of some rhetorical strategies with their functions in three short stories : Wilde's "The Happy Prince", Saki's "The Open Window" and Poe's "The Black Cat" and two novels : Dicken's "Hard Times" and Hemingway's "The Old Man and the Sea" . It argues, for example that these resources rhetorically influence beliefs, attitudes, expectation and modes of interrelating. The third part presents the quantitative and qualitative results with their discussion. The paper ends with a conclusion .
\end{abstract}

Keywords:Hedges-point of view, literary text, politeness, indirectness.

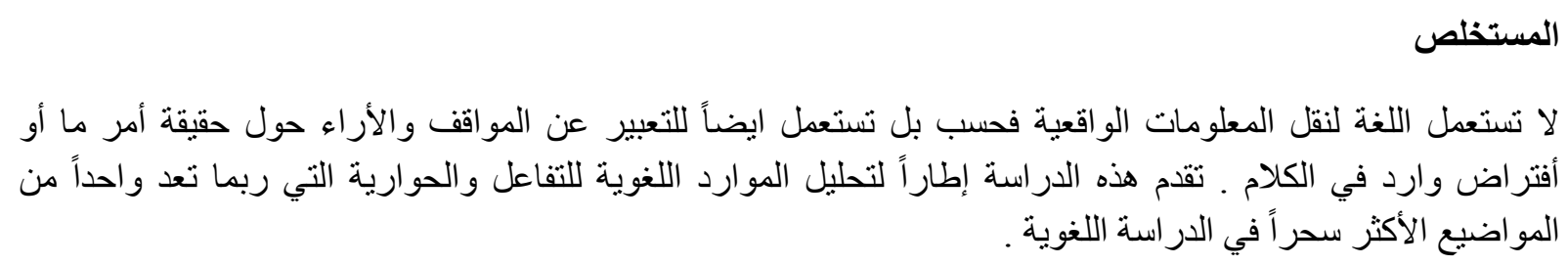


محاو لات عديدة أجريت لأدر الك كيف ان التكييف الفكري من خلال در استه كجزء من علم اللغة النصي أو النصية بأستخدام

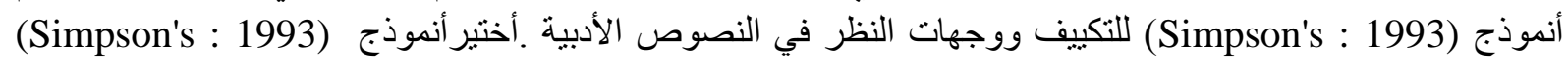

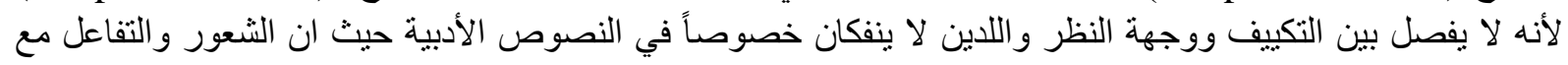

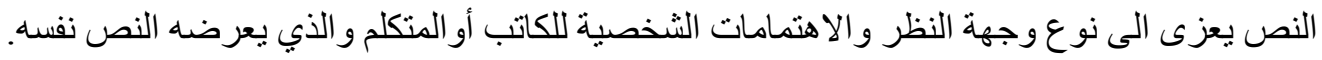

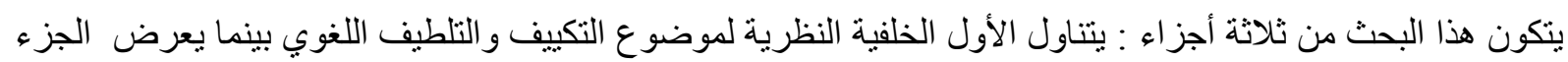

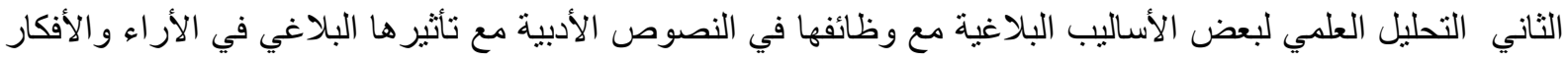

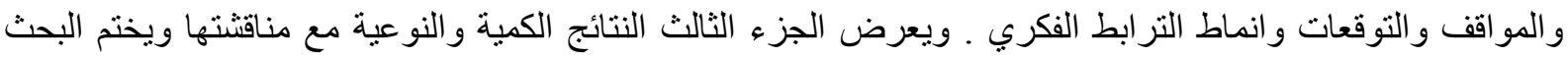
بالنتائج .

\section{1-Introduction}

The interpersonal function of language is one of the most complicated subjects in language study. It "deals with sourcing attitudes and the play of voices around opinions in discourse" (Martin and White 2005:35). In this paper hedging is looked at as an aspect of pragmatic competence. In order to demonstrate the interactive aspects of hedges, the researchers will examine the use of such devices in literary texts .

The theoretical framework for the analysis of such interactive strategies is explored by three sections. In section one the evolution of hedging into the linguistic literature is described. Section two presents the properties of hedges and the devices through which hedging is implemented. In section three the relationship between hedging and the discourse effects of indirectness, evasion, power and solidarity is investigated .

As there is no one -to -one correspondence between form and function, the social contexts determine the devices the writers employ. Moreover it is noted that any writer has an ideology or philosophy behind different types of hedges he/she uses which construe his/her judgement about events or phenomena in a particular context .

\section{2- Review of Literature}

Weinreich (1966) is the pioneer who talks about "metalinguistic operators" . He argues that for every language "metalinguistic operators" such as truly, strictly speaking , .... function as instructions for strict interpretation of a text. However, it was Lakoff who popularized the concept of hedging through his studies. He claims that any attempt to limit language sentences as having sharp rather than vaguely boundaries would distort the natural language concepts (1977: 195) .

Fraser (1975) introduces what he calls "hedged performative" where certain performative verbs such as apologize, request ... when preceded by a modal verb will mitigate the illocutionary force of the speech act designated by the verbs as in :

e.g./ I should apologize for running over your cat . 


\section{University of Thi-Qar Journal Vol.11 No.1 Mar 2016 \\ Web Site: https://jutq.utq.edu.iq/index.php/main Email: journal@jutq.utq.edu.iq}

In this example, it is still an apology but it is less strong than if "should" were not present (p 195) .

Brown and Levinson $(1978,1987)$ develop fully the speech act aspect

of hedging. They evolve the politeness phenomenon by which hedging is termed as "Speech Act Hedging" .

Prince et al (1982:85) make a clear distinction between two types of hedges : the first one is propositional hedging Which involves the propositional content and affects the truth condition of the proposition conveyed.The second type is concerned with the relationship between the propositional content and the speaker which indicates the speaker's commitment to the truth of the propositional content conveyed (speech act hedging) .

Equally important, Prince etal (1982) divide up the hedges into two classes . The first is "Approximators" that operates on the propositional content. This class is subdivided into "Adaptors" such as somewhat, sort of , almost .... and "Rounders" which convey a range such as about, something around, approximately. The second is "Shields" that involves the relationship between the propositional content of the message and the speaker's commitment towards it, in other words, the level of uncertainty. There are also two subclasses : "Plausibility Shields" or what Martin and White (2005:35) call "Expand engages Entertain" which are expressions that account for doubt such as (I think, probably, I don't see that ...) . The second subclass is "Attribution Shield's" which is either Acknowledgment (he argues that ... it's said that ... ) or distance (according to her/his estimates .... ).

Similarly Hubler (1983:86) differentiates between two terms that are"understatement " and "Hedge" although he uses "understatement" as a cover term for both . Understatement is concerned with the propositional content of the sentence whereas "Hedge" concerns the speaker's attitude to the hearer regarding the proposition and the validity of the proposition the speaker makes. Hubler's division is similar to that of Prince etal (1982), whose Approximators correspond to the Hubler's understatement and whose Shileds correspond to Hedges .

Today, there is an agreement that hedging is a rhetorical strategy a speaker uses to either express his/her lack of commitment to the truth of proposition or full commitment to the force of the speech act being conveyed .

\section{3- Properties of Hedges}

Whatever headings under which hedges are treated, they provide the means by which a speaker / writer can take a stance towards the various points of view or social positioning being referenced by the text (white , $2005: 259$ ). In other words ,they show how interpersonal function of discourse is presented by some devices that operate rhetorically to influence beliefs, attitudes, expectations and modes of interrelating . 


\section{University of Thi-Qar Journal Vol.11 No.1 Mar 2016 \\ Web Site: https://jutq.utq.edu.iq/index.php/main Email: journal@jutq.utq.edu.iq}

Martin (1992:165) suggests a category of "Engagement" as a cover -term for resources of intersubjective positioning. Stubbs (1996:220) proposes that all wordings by which speakers or writers moderate their attachment to , or detachment from the proposition should be extended well beyond the category of modality which is expressed by the modal verbs .

\section{4- Simpson's (1993) Model of Modality}

Simpson's (1993) model of modality is closely connected with Flower's (1977) original model of point of view. Simpson (1993:46) suggests that much of the feel of a text is attributable to the type of point of view or authorial interests it exhibits. In the simplest sense , a writer's /speaker's particular style of conceptualizing a worldview is indicated by the point of view he/she adopts .

Simpson (1993:47) broadly divides modality into four systems : the deontic , epistemic , boulomaic and perception system . Regarding the deontic system, he argues that modality is the model system of "duty" expressing a speaker's /writer's sense of obligation towards the management of certain tasks. It is often realized by the modal auxiliaries such as may, should, must . It is typically concerned with actions that direct human behaviour .

Contrary to deontic modality epistemic modality expresses a speaker's degree of confidence in the truth of the proposition stated . It is conceived by the modal auxiliaries such as could, may, might (ibid:48).

Boulomaic system, according to Simpson's (1993) classification of modality, is concerned with a speaker's / writer's desires and wishes. It is generally realized by such verbs (hope, wish, regret). On the other hand the perception system is a sub-system of epistemic modality that refers to the degree of commitment to the truth of a proposition as predicted on some reference to human perception, normally visual perception . It is usually referred to by such verbs (look, see ...) (ibid).

Equally significant, Simpson's (1993) identifies three types of epistemic modality in which external point of view is sub-divided into narratorial mode and reflector mode . A narratorial mode in return is divided into positive, negative and neutral . On the other hand, a reflector mode is divided into positive, negative and neutral. As shown in Figure 1 below: 


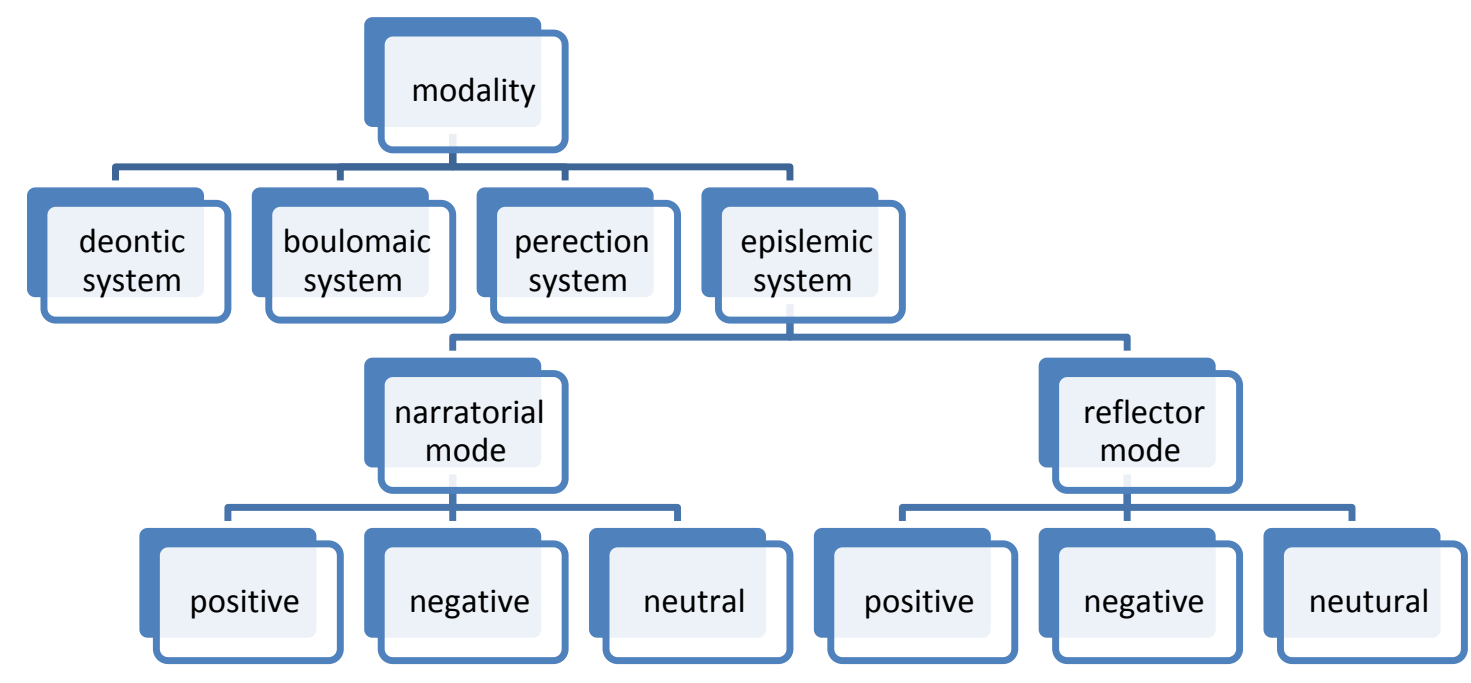

Figure (1): A Summary of Simpson's (1993) Model of Modality

Kiparsky (1970) proposes a similar catergorization of epistemic modality in which he investigates three types : factive, contra - factive and non - factive. The factive utterance commits the writer / speaker to the truth of the proposition such as any predicator that behaves like "know" can be said to have the property of factivity .

e.g. / 1- I Know that Tahran is the capital of Iran .

2- It is amazing that they survived.

The contra - factive utterance, on the other hand commits the writer not to the truth, but to the falsity of the proposition. Such utterances are wishes and so - called unreal conditionals .

e.g./ I wish he had been to Tahran .

Finally the non factive utterance commits the writer to neither the truth nor the falsity of a proposition . such an utterance is presented by such verbs (think, may ....) or the expression (it is possible that ...).

In the simplest sense, hedging indicates a speaker's or writer's special way of conceptualizing a world view and in relation to the analysis of such rhetorical strategy. 


\section{University of Thi-Qar Journal Vol.11 No.1 Mar 2016 \\ Web Site: https://jutq.utq.edu.iq/index.php/main Email: journal@jutq.utq.edu.iq}

\section{5- 1 Hedging and Indirectness}

Conveying unstated meaning by ellipsis and indirectness is a fundamental aspect of language that literary and conversation analysts are interested in. Tannen (1984:11) develops her theory of conversational style by taking R. Lakoff 's theory of politeness as a model . Politeness is one function of hedging in which three principles can be illustrated. Tannen refers to such principles as : distance, deference and camaraderie. (ibid) .

Tannen states that either formal expressions or technical vocabulary can be used to exclude personal emotions. In Brown and Levinson's terms this principle would be equivalent to negative politeness. To show the deference she affirms that the speaker tends to say things hesitantly by not stating one's will clearly or directly. In this sense ,the speaker abandons to the power of the hearer by leaving the option of decision to him or her . This principle involves the sense of indirectness which is related to the negative face rule in Brown and Levinson's theory (ibid) .

To enhance closeness between the speaker and the hearer and to emphasize equality between them the speaker tries to be indirect to show that he or she and the hearer understand each other completely and there is no need to talk directly. In this case, indirectness brings what we call compatibility (Tannen , 1989:22) .

It is worth to mention that people in the real world often try not to be relevant, that is to say they give hints, association clues or presuppose instead of making direct requests (Brown and Levinson, 1978:213-229) .

e.g./ It's rather cold here . (shut the window).

In this case, people violate one of Grice's cooperative principles (the maxim of relevance) .

Interestingly, sometimes one hedged expression may violate all Grice's cooperative principles. Thus, people don't always follow these principles. They do so in order to save their faces when their negative faces are threatened. The expression "I don't know" or "I do not remember very well" are used and repeated to avoid giving specific answers to the questions that threaten the hearer's negative face. This is a violation of the maxims of quantity since the answerer does not give enough information, and the maxim of quality since he or she is not sincere when he or she answers the questions. It is also a violation of the maxim of manner by answering ambiguously .

\section{5-2 Power, Solidarity and Hedging .}

Tannen (1986:93) discusses power and solidarity in relation to involvement and independance. She points out that in read life we don't always tell the others straightforwardly what we want, but we make them realize that we want them to do so . In this way of manipulation power can disguise or masquerade as solidarity. It is so when 


\section{University of Thi-Qar Journal Vol.11 No.1 Mar 2016 \\ Web Site: https://jutq.utq.edu.iq/index.php/main Email: journal@jutq.utq.edu.iq}

indirectness is not used only for selfish aims to manipulate others and by which the people of higher status control people of lower status. In such a way it is an example of tact, and making our life and interrelation go smoothly .

\section{6- Methodology}

Hedges as an aspect of pragmatic competence possess different forms. It is claimed that one kind of these devices may be used at a higher rate than the other in different contexts .

Fairclough $(1992,1995)$ claims that in literary narratives the propositions the writer makes are influenced by his / her idea and ideology . Our hypothesis is that in such texts hedges especially epistemic modals will be prominent . In addition we hypothesize that different sorts of devices are employed in different texts for expressing different types of modality, that is epistemic, deontic, boulomaic and perception modality. For instance, some special epistemic modals that imply the possibility like ; can , may and might are supposed to be of high use and frequency in literary texts in which the certainty of the propositions may not be committed by the writer .

The analysis of data in this paper depends on both the quantitative and qualitative approaches by adopting Simpson's (1993) model of modality and point of view .

Hence, this study attempts to explore some pieces of three short stories and a novel and a novella which the researchers have randomly selected from Dicken's "Hard Times" , Hemingway's "The Old Man and the Sea" , Wilde's "The Happy Prince" , Saki's , "The Open Window" and Poe's "The Black Cat" .

\section{7- Data Analysis}

In the analysis below, we will explore the ways in which the hedged expressions guide the reader to an interpretation that best fits the writer's intentions. We will identify the types of meaning conveyed by hedged expressions and the role their meaning plays in the interpersonal function of language. For instance, politeness, indirectness and solidarity, all these meanings can be expressed by different types of modality which is treated under such heading "Hedging" . To investigate the way hedges are capable of manifesting interpersonal function some pieces of literary narrative - three short stories and one novel and one novella - were selected randomly and analyzed statistically in the framework of the classification discussed earlier .

1- I shall just give letters of introduction to all the people I know there. Some of them, as far as , I can remember were quite nice . "The Open Window " .

In this extract, the hedged device "as far as" belongs to what Prince et al. (1982) call Plausibility "shields" by which the relationship between the propositional content and the speaker is changed by associating a level of uncertainty with respect to speaker's commitment. Also in this extract of the short story "The Open Window" the 


\section{University of Thi-Qar Journal Vol.11 No.1 Mar 2016 \\ Web Site: https://jutq.utq.edu.iq/index.php/main Email: journal@jutq.utq.edu.iq}

expression "as far as" relates doubt that some of the dwellers of this rural retreat were quite nice.

2- A most extraordinary man, Mr. Nuttle said Mrs. Sappleton "could only talk about illness and dashed off without words of good - bye or apology when you arrived . One would think he had seen a ghost" . "The Open Widow".

A belief and high degree of confidence in the proposition can be textualized by modals like "will" and "would" as in the example above in which three hedged devices "one would think" can be used. The effect of hedging is found in the interpretation of the utterance rather than in the semantic meaning of the sentence uttered, where the interpretation depends on the context of the utterance. Mrs. Sappleton said this expression with certainty and assurance, she believes that the proposition that is Mr. Nuttl's escaping from the room to avoid imminent collision, is true in her opinion .

3- .... "He is as beautiful as a weather cock", remarked one of the Town councilors who wished to gain a reputation for having artistic tastes ; only not quite so useful, he added, fearing most people should_think him unpractical which he really was not . "The Happy Prince"

The epistemic modal "should" in the above extract expresses what Lakoff (1972) calls "prepositional hedging" with which the writer expresses the ideology of probability of the proposition within the utterance. By such a modal, the writer wants to express the idea about which not only he, but also others have the same prediction .

4- Here at least, then, my labor has not been in vain" . "The Black Cat".

The narrator uses the hedged expression "at least" as a safeguard against being later proven wrong or blamed. He makes his best efforts to hide the mark signs of his crime, that is killing his wife and burying her under old ruins. This tentative usage of vague expression is close to what Prince etal (1982) call "plausibility shields".

5- This had probably been done with the view of arousing me from sleep . " The Black Cat"

The modal adverb of likelihood "probably " makes the reader focus on the rather large likelihood that the narrator in The Black Cat would be aroused from sleep if he carried out his crime of hanging the cat then throwing it through an open window. This view causes him to be abnormal. Thus the vague expression is more useful to make clear the narrator's intention that he was noted for the docility humanity and fondness of animals .

6- When Mr. Gradgrind tells his daughter Louisa of Bounderby's proposal of marriage, he is completely unconscious of the indication of her disappointment in life .

She says, "Father, I have often thought that life is very short, and Gradgrind says in return that "It is short , no doubt my dear ".Hard Times" 


\section{University of Thi-Qar Journal Vol.11 No.1 Mar 2016 \\ Web Site: https://jutq.utq.edu.iq/index.php/main Email: journal@jutq.utq.edu.iq}

The adverb of frequency "often" in this example like other adverbs of frequency, shares many of the characteristics and functions of vague quantifiers. The vague adverbs of frequency convey information about the frequency of events but do not provide either exact absolute frequency or an exact relative frequency (Moxey and Sanford , 1997:218). "Often" here seems to indicate "plus for frequency" because Louisa wanted to talk about something, that is her thinking about shortage of life, more often but it does not matter whether she had thought one time out of ten or nine times out often. The point is, in a society based on utilitarianism, it is difficult to be sensible of human emotions

7- I hope you don't mind the open window "said Mrs. Sapplaton briskly. "The open Window".

The modal lexical verb "hope" indicates the wish and desire of the speaker. Such a verb is classified as boulomaic modality by which the writer /speaker can show that the addressee's wants should be thought of as desirable. In other words, it expresses what Brown and Levinson (1978:166) call "positive politeness" .

8- My dear Louisa, you are a woman ! My dear, I must speak with you alone and seriously . Com to me in my room after breakfast tomorrow, will you?

Yes, father. "Hard Times".

Usually the modal verb "must" gives us a sense of obligation on the hearer's /reader's part to express deontic modality, but in this extract it gives a sense of inference on the writer's part . By using such a modal verb the writer/speaker draws a conclusion on the basis of available evidence that Mr. Bounderby is the suitable husband of her daughter Louisa .

It is worth to note that modal expressions have in themselves a rather skeletal meaning and it is only in combination with the background context they take on a particular shade of meaning such as inference, obligation, permission .... In other words the modal meanings should be seen as the outcome of context - dependency (Kratzer, 1981:55).

The epistemic meaning of must implies that the writer judges the proposition to be necessarily true, or at least to have a high likelihood of being true .

9- .... It was papa made me leave . I am a boy and I must obey him .

I know, the old man said, It is quite normal .

"He hasn't much faith" .

"No, the old man said . "But we have, haven't we ? "The old Man and the See".

In this extract, Hemingway wants to present "Santigo" , the hero of the novella, The Old Man and the Sea, as a man with full faith who does think about the meaning of life and accepts what life has given him without complaint. To express empathy and display 


\section{University of Thi-Qar Journal Vol.11 No.1 Mar 2016 \\ Web Site: https://jutq.utq.edu.iq/index.php/main Email: journal@jutq.utq.edu.iq}

euphemistic reticence in the expression of opinion and attitude, the writer uses a negative tag question .

According to Leech (1983:101-102) negation may also be a hedging or mitigating device which displays tentative attitudes or hedge a suggestion or an opinion . Additionally, the tag question in this example is used as a medium to exchange information in a way the meaning of a clause is qualified so as to reflect the speaker's judgement of the likelihood of the proposition it expresses being true (Quirk etal , 1985 :219). This would then mean that Santiago is not a religious person, but his religious references show that he is very familiar with Roman Catholic Saints and prayers .

10- Then he began to pity the great fish that he had hooked . He is wonderful and strange and who knows how old he is, he thought . Never have I had such a strong fish nor one who acted so strangely. Perhaps he is too wise to jump. But perhaps he has been hooked many times before and he knows that this is how he should make his fight. He can not know that it is only one man against him, nor that it is an old man .

The hedged device "perhaps" is the most frequent device in literary texts. This may be due to the nature of the literary discourse in which the receivers are led by the narrator or the fiction dialogue to anticipate certain future events and create, within themselves, a sense of suspense and anticipation. In such common narrative situation the speaker attempts to trigger a particular goal or belief in the receivers. Through the author's revelation of Santiago's own thoughts and the conversations between Santiago and his young companion, manolin and with the big fish "Marlin" , readers come to sense that despite his setbacks and shortcomings, Santiago remains proud of himself and this makes his humility .

11- Louisa sternly blames her father for his thoughtless at first :

"Would you have doomed me, at any time, to the frost and blight that have hardened and spoiled me ? would you have robbed me ..... of the immaterial party of my life .....?

"Oh no - no, Louisa"

Yes, father if I had been stone blind, if I had groped my way by my sense of touch , and had been free, while I know the shapes and surfaces of things, to exercise my fancy some what, ..... I should have been a million times wiser, happier , .... More innocent and human in all good respects than I am . All Gradgrind can say is that "I never know you were unhappy, my child ". "Hard Times".

The syntactic configuration "if" with its verbs refers to the condition under which the speaker makes the utterance. In this extract such an expression emphasizes the dialogic and communicative function of the hedges. This marker has a rhetorical orientation which indicates relation of status .By repeating it the speaker( Louisa ) introduces more than one viewpoint that is so called unreal conditional in which the writer /speaker shows his commitment to the falsity of the proposition . 


\section{University of Thi-Qar Journal Vol.11 No.1 Mar 2016}

Web Site: https://jutq.utq.edu.iq/index.php/main Email: journal@jutq.utq.edu.iq

\section{Results and Discussion}

To investigate the significance of hedging representing the interpersonal function through different types of modality, the lexical expressions such as adverbs of frequency, syntactic configurations such as tag questions, and vocalizations such as ah, oh, ..., we try to validate our hypothesis that epistemic modality is the most prominent type .

The results of the descriptive analysis demonstrate that totally (568) hedged devices are employed in our selected literary texts which have been used as the data corpus - As shown in Table (1) epistemic modality has been used (249) times with the highest percentage (43.83\%) . It is shown also that the frequency of perception modality like, observe, see , ....) scores the lowest one because such devices are expected to be highly used in the scientific texts which demonstrate facts rather than idiologies .

Table (1) An Investigation of the Frequency and Percentage of Modality in the Literary Texts .

\begin{tabular}{|l|l|l|}
\hline Modality & Number of Items & Percentage \\
\hline Epistemic & 249 & $43.83 \%$ \\
\hline Deontic & 100 & $17.60 \%$ \\
\hline Boulomaic & 69 & $12.14 \%$ \\
\hline Perception & 5 & $0.88 \%$ \\
\hline Others & 125 & \\
\hline Total Number of Hedges & 568 & \\
\hline
\end{tabular}

Table (2) An Investigation of the Frequency of the Most Frequent Modal Expressions In the Literary Texts .

\begin{tabular}{|l|l|l|}
\hline Modality & Number & Percentage \\
\hline Epistemic & 41 & $\mathbf{1 6 . 4 6 \%}$ \\
\hline Factive & 77 & $\mathbf{3 0 . 9 2 \%}$ \\
\hline Contra - Factive & 131 & $\mathbf{5 2 . 6 1 \%}$ \\
\hline Non - Factive & 49 & $\mathbf{4 9 \%}$ \\
\hline Deontic & 45 & $\mathbf{4 5 \%}$ \\
\hline Must & \multicolumn{2}{|l}{} \\
\hline Should & 30 & $\mathbf{4 3 . 4 7 \%}$ \\
\hline Bolumaic & 33 & $\mathbf{4 7 . 8 2 \%}$ \\
\hline Wish & \multicolumn{2}{|l}{} \\
\hline Hope &
\end{tabular}




\section{University of Thi-Qar Journal Vol.11 No.1 Mar 2016}

Web Site: https://jutq.utq.edu.iq/index.php/main Email: journal@jutq.utq.edu.iq

\begin{tabular}{|l|l|l|}
\hline Adverbs of Frequency & 58 & $\mathbf{4 6 . 4 \%}$ \\
\hline Well & 31 & $\mathbf{2 4 . 8 \%}$ \\
\hline Tag - Questions & 10 & $\mathbf{8 . \%}$ \\
\hline
\end{tabular}

Table (2) shows the highest quantity and percentage of non- factive $(52.4 \%)$ with the lowest quantity and percentage of factive. The highest frequency of non - factive utterances, in which the writer shows no commitment to the truth or the falsity of a proposition, indicates that such vague expressions are more useful than a precise likelihood in which the speaker's / writer's intention will be clear. In addition, the use of such expressions like probably, may be , it is possible and so on does not admit that this proposition or statement is contrary to the reader's / listener's expectation .

The statistical analysis in the table (2) demonstrates that the verb "must" with the sense of inference rather than obligation is of high percentage (49\%). The propositions are interpreted in terms of the writer's attitude and opinion towards the events rather than reflecting of the writer's preoccupations of what the behaviour of the reader's should be . On the basis of personal and environmental knowledge, the writer makes his inferences .

It is noted in table (2)that the frequent use of the verb (hope) with its percentage (47\%) among other boulomaic devices which has the percentage $(12.14 \%)$. In our corpus under investigation, the ideology behind the verb hope is "possibility" through which the writer wants to say that he /she has no sufficient personal or environmental knowledge or an available evidence to talk frankly about the events .

Concerning the other hedged expressions, the adverbs of frequency, especially the adverb "never" is of the highest frequency . Vague adverbs of frequency participate other vague quantifiers in their characteristics and functions to convey information about the recurrence of events rather than an exact absolute recurrence. Equally important, these adverbs convey the speaker's own expectations and, further, may convey the speaker's / writer's beliefs about the listener's /reader's anticipations .

The marker "well" is used (31) times with the percentage (24.8\%) . It has been employed to understate the expression of utterance in specific contexts. It occurs in contexts of impositive statements, suggestions and explainations to express the speaker's attitude towards the propositional content and the hearer. Consequently this marker conveys the implicature of the speaker's tendency to behave in a deferential way towards the addressee .

It was expected that tag - questions are of a higher use in the corpus, since the literary texts firmly rely on fiction dialogue rather than real - life conversations. In such conversations, the conversationalists can rely on rich non - linguistic resources of contexts, where as writers are forced to created context mainly through language (Ruhlemann , 


\section{University of Thi-Qar Journal Vol.11 No.1 Mar 2016 \\ Web Site: https://jutq.utq.edu.iq/index.php/main Email: journal@jutq.utq.edu.iq}

2007:75) . This would then mean that declarative tag - questions may be seen as heteroglossic in acknowledging alternative viewpoints rather than reflecting the speaker's state of knowledge (ibid 77) .

\section{Conclusion}

It becomes clear that language is employed not only to express facts but also to express opinions, ideas and ideologies about the events. Such function is highly represented by hedging . Mastering the art of hedging is one feature of the pragmatic ability which enables us to communicate effectively in language. Understatement messages, equivocation and ambiguity are appropriate means to communicate with others. Such properties of hedging are good - enough substitutes for precise expressions and they are preferable ones because of their greater efficiency .

Literary texts provide useful tools to investigate hedges and to develop an awareness of how language functions. The frequency and percentage of hedges differ from one genre to another. In literary texts the epistemic modality that conveys a certain ideology of uncertainty about the proposition is of great use. Consequently, this encourages us to discuss the suitability or appropriateness of specific hedged expressions to uncover and explain the hidden meanings .

\section{References :}

- Brown , P. and Levinson , S. (1978). "Universals in Language Usage : Politeness Phenomena" . In E. Goody (ed.), Questions and Politeness : Strategies in Social Interaction . Cambridge : Cambridge University Press , PP. (56-289).

_(1987). Politeness : Some Universal in Language Usage. Cambridge : Cambridge University Press .

- Fairclough , N.(1992) (ed.). Critical Language Awareness . New York : Longman .

_(1995) . Critical Discourse Analysis : The Critical study of Language . New York :Longman

-Fraser , B.(1975) . "Hedged Performatives" , In P. Cole and J.L. Morgan (eds.), Syntax and Semantics . New York : Academic Press, Vol.3,PP (187-210).

-Hubler, A. (1983). Understatements and Hedges in English. John Benjamins, Amsterdam .

- Kiparsky , P. (1970) . Fact in Bierwisch , M.and K.E Heidolph . Progress in Linguistics, Mouton, The Hague . 


\section{University of Thi-Qar Journal Vol.11 No.1 Mar 2016}

Web Site: https://jutq.utq.edu.iq/index.php/main Email: journal@jutq.utq.edu.iq

- Kratzer , A.(1981). "The Notional Category of Modality " . In H.J. Eikmeyer and H. Rieser, (eds.) , Words , Worlds, and Contexts . New Approaches in Word Semantics . Berlin : deGruyter, PP (38-74).

- Lakoff , G. (1972) . "Hedges : a study in Meaning Criteria and the Logic of Fuzzy Concepts

" . Papers from the English Regional Meeting of Chicago Linguistic Society PP (183-228) .

-Leech, G.(1983) . Principles of Pragmatics . London : Longman .

-Martin, J.(1992) . English Text : System and Structure . Amsterdam : John Benjamins .

- Martin , J. and White , P. (2005) .The Language of Evaluation : Apprasial in English . New York : Palgrave Macmillan .

-Moxey, L. and Sanford, A. (1997) . "Choosing the Right Quantifier" . In Givon , T. (Ed.) Conversation : Cognitive, Communicative and Social Perpectives. John Benjamins, Amsterdam pp. (207-231).

-Prince , E. , Frader , J. and Bosk , C.(1982) "On Hedging in Physician - Physician Discourse " . In R. J. Di Pietro (ed.), Linguistics and the Professions . Proceedings of the Second Annual de laware Symposium on Language Studies . Norwood, NJ : Ablex , (83-97).

-Qurik , R. , Greenbaum , S. , Geoffery, L. and Svartvik , J. (1985) . A comprehensive Grammar of the English Language. Harlow : Longman .

- Ruhlemann , C. (2007) . Conversation in Context : a corpus - Driven Approach . London : Continuum .

- Simpson, P. (1993) . Language, Ideology and Point of View . London : Routledge .

-Stubbs , M. (1996) . Towards a Modal Grammar of English : A Matter of Prolonged Fieldworld .In Text and Corpus Analysis, PP. (196-228) . Oxford : Blackwell .

-Tannen , D. (1984) . Conversational Style : Analyzing Talk Among Friends . Norwood , N.J : Ablex Publishing Corporation .

- (1986) . That's Not What I Meant! New York : Ballantine Books .

- (1989) . Talking Voices : Repetition Dialogue, and Imagery in Conversational Discourse . Cambridge : Cambridge Universit Press .

-Weinreich , U. (1966) . "On the Semantic Structure of English" . In J.H. Greenberg (ed.), Universals of Language . $2^{\text {nd }}$. Edition Cambridge, MA : MIT Press (142-217) .

-White , P. (2005) . The Appraisal Website : The Language of Attitude , Arguability , and Interpersonal Positing . Accessed April (2010) : <http : // www. Grammatics . com>

\section{Appendix}




\section{University of Thi-Qar Journal Vol.11 No.1 Mar 2016}

Web Site: https://jutq.utq.edu.iq/index.php/main Email: journal@jutq.utq.edu.iq -Edgar Allan Poe . The Black cat .

-Earnest Hemingway . The old Man and the Sea . Penguin Books.

-Oscar wilde . The Happy Prince .

-Saki(H.H.Munro ) . The Open Window 